\title{
Investigating the Impact of Nature in Designing Cultural Environments for Children
}

\author{
N. SADAFI ${ }^{1}$, L. AZHDARI ${ }^{2}$ \\ 1Payame Noor University (PNU), Dept. of Art and Architecture ,P.O. Box 19395-3697, Tehran, Iran. \\ nsadafi@pnu.ac.ir \\ 2Payame Noor University (PNU), Dept. of Art and Architecture ,P.O. Box 19395-3697, Tehran, Iran. \\ Azhdari.1394@gmail.com
}

\begin{abstract}
There is a tendency to communicate with nature in human beings as a set of emotional experiences. This study investigates the impact of organic architecture in creating cultural spaces for children. The concepts of nature, naturalist architecture and children educational psychology, from the perspective of scholars and researchers in this area are investigated. The children's perception of nature and their feelings were assessed and one hundred forty respondents among the instructors of cultural centres in different regions of Tehran have answered the questionnaires. To investigate the hypotheses, Univariate $T$ - test and $F$ - test were applied. The results showed that the stimulation of the natural environment has a positive and meaningful effect on curiosity, participation, and fantasy in children, while they show their impressions of nature indirectly. Therefore, designing applicable spaces according to children's physics, using appropriate colours and furniture as well as more environmentally-related spaces, can have positive effects on social participation, intuitive and verbal skills of the children
\end{abstract}

Keywords: Nature, organic architecture, children, cultural centres

\section{Introduction}

The behavioural reactions of each training environment are affected by various factors such as symbolic, organizational, physical, and psychological features (Mortazavi, 1997). The effects of factors are not direct and they are positively moderating the influence of each other (Muscovitch, 1980). Studies on the environmental priorities of children can be divided into two groups of their favourites in physical spaces and things that they don't like or make them uncomfortable. It is also substantial to understand the full picture of the suitable environment for children, the awareness of places that children don't like or even fear. These places are parts of the reality of the children's world, where it is possible to interact with other children and adults. Architectural space may be described as a growth context for children, along with other factors such as play, art, and nature.

Studying the effects of coexistence with nature to reduce and compensate environmental crises and stress as well as the importance of direct environmental interactions in childhood is one of the main concerns of researchers in this field (Fjørtoft, 2004) (Shamsuddin \& Said, 2008) (Profice ,2018). Because nature is a necessary complement to the built environment, utilization of the environmental felements is unavoidable, especially if this place belongs to children (Beery \& Lekies 2018) (Mygind et al., 2019). Studies indicate that in addition to improving the cognitive, emotional, physical and social functions, the 
immediate experience of children with nature leads to an emotional bond and the sense of responsibility of a child to nature, which will continue during adulthood (Tetsuro Hosaka et al., 2018). Moreover, a child's ability to understand and express the language, image, and moral judgment will be increased in relation with nature (Frumkin \& Fox, 2011). Therefore, the form of architectural space, defined by the type of activity, must be accompanied by the freedom of communication with nature to guide a child indirectly towards educational goals.

The changes in the lifestyle and the advancement of technology, especially in large cities, have changed the interactions between children and nature. The arrival of electronic devices and technologies confined their lives to pre-established and monitored moments. Infact the relationship between children, and nature has been cut off in the world today and it is necessary to re-establish this connection. Present study tries to explore the relationship between designing a comprehensive cultural place dedicated to children affected by the science of naturalism.

\subsection{Nature}

In Persian language, the word nature refers to the essence and what people have created for it. It also refers to the water, the flower, the gem, the taste, and creation (Dehkhoda, 1998). In some opinions, nature contains human material, natural environment, and built environment that can be changed and measured (Hagan, 2012). In another view, nature refers to areas where there are no artificial artifacts such as parks and natural forests. Of course, it does not mean the lack of human management in the environment (Balling \& Falk, 1986). The natural rate of the environment affects the way people think about that environment. Elements in natural context, in comparison with elements of a manmade surroundings, are subtler and diverse, with less control. In this way, more variability is possible in natural areas. Despite the presence of such features, it is difficult to find an exact explanation of nature or natural elements (McAndrew, 2008).

\subsection{Psychology of child development}

Humans inherit two main desires: One is harmony, and the other is organization. The purpose of harmony is how to interact with the environment, and the organization considers the recognition system. The stages of growth is divided into four categories; sensorimotor skills (from birth to two years), pre-operative (from two to seven years old), tangible performance (from seven to eleven years old), and formal or abstract operations (eleven to fifteen years old). In this theory at the stage of the sensorimotor skills, a child discovers the world through his senses and motor movements, and in the pre-operative stage gradually the symbolic thinking appears. During the period of tangible performance the children will think logically, according to the objective and tangible affairs (not abstract and single). In the last stage of the growth, the adolescents think about subtle things that are not available (Hosseini, 1997).

In another theory, the stages of mental development include the motion, visual, and the symbolic parts. According to this theory, children in the motion stage of development represent events that they experience as movements or action responses. At the visual stage, the children conserve the events in 
the form of mental images. And at the symbolic phase, he has acquired a typical system, the most important of which is language (Seyf, 2004).

Accordingly, the essential requirements of a child development include:

- The necessity of understanding the environment and the spread of cognition

- Health, physical security and the development of body skills

- Satisfying emotions, linking to the environment and spreading motivations

These necessities emphasize the role of the environment and the available facilities for independent mobility, the development of physical skills, and the creation of emotional and mental links in children. Psychologists believe that children should be involved in the environment's development processes (Tavakoli \& Saeedi Rezvani, 1997). Because they are in contact with the surrounding environment, and usually aware of how the decisions are affected by the context. The perception and understanding of a child should be considered as a tool for better notation, imagining, abstracting and illustrating (Gharebigloo,2010). Understanding the intrinsic needs of a child and the demands of the community are intimately connected, and ignoring the wishes of a child would create many social problems.

\subsection{Children and nature}

Natural environments affect humans not only by their physical aspects but also their psychological impacts (Pyle, 2002). The difference in the appearance of natural elements such as lines, textures, colors, high contrasts, movements, and complex details, enhances the diversity of mental images, curiosity, and imagination of children (Shafaee \& Madani, 2010). The ability to establish this relationship between children and nature is possible in different ways. The first method is to create a situation for direct experience and a child exposure to nature. This condition mainly occurs in the outside environment and independent of the physical areas. Second method which called indirect understanding, children's physical communication is associated with more restraint and surveillance, and natural places are under the control and supervision of humans. Places like zoos, aquariums, botanical gardens or museums of natural sciences such is the case. It is also possible to create a suitable view from the inside of the space to the natural landscape, to bring nature into the children's surroundings, and provide the indirect exposure for children. In modern societies, due to a limitation in direct contacts, a third kind of experiencing of the nature so-called symbolic experience also occurs. In this case, physical contact does not exist, and a child faces a representation of nature through television, films, computer, books, and magazines (Kahn, \& Kellert, 2002)( Joy, 2007) (Tabatabaiyan et al., 2014).

\begin{tabular}{|c|c|c|}
\hline Kind of relationship & Area & Solution \\
\hline Direct contact & \multicolumn{2}{|c|}{$\begin{array}{l}\text { Creating opportunities for child exposure in natural } \\
\text { environments }\end{array}$} \\
\hline \multirow[t]{5}{*}{ Indirect contact } & \multirow[t]{4}{*}{ In buildings } & Planting in building \\
\hline & & $\begin{array}{l}\text { Visibility to green space from inside the } \\
\text { building }\end{array}$ \\
\hline & & Entering natural light into the building \\
\hline & & Using natural images in the interior spaces \\
\hline & In the city & building parks and green spaces \\
\hline
\end{tabular}




\begin{tabular}{|l|l|l|}
\hline & & Building green spaces in neighborhoods \\
\cline { 3 - 3 } & & Social gardens \\
\hline Symbolic contact & $\begin{array}{l}\text { Biophilic } \\
\text { Architecture }\end{array}$ & Natural shapes and forms \\
\cline { 3 - 3 } & & Making movies and animations \\
\hline
\end{tabular}

Table1. Different ways of establishing the relationship between children and nature

According to conducted studies, nature's experience has a direct effect on improving the physiological and cognitive performance, social and emotional development of the children:

- It causes muscle relaxation, low blood pressure, and mental stress, and reduces the symptoms of the disease (Taylor et al., 2001)( Browning et al., 2014). Also, natural environments create opportunities to explore, experience, and play. These are satisfactory incentives to develop cognitive and visual skills, brainstorming, and focusing on children (Zamani, 2009).

- Nature allows children to develop emotionally in a various ways, such as a sense of satisfaction, pleasure, fear, anxiety, danger, and horror. It gives a passion for living and prepares a child for learning throughout life [13]. Also, playing in the natural environment increases the ability to develop social and behavioural skills and self-confidence in children by creating a sense of participation and competition with others (Zamani, 2009).

In the past, children were free to play, discover, and interact with nature without limitation.Today, the exploration of the environment for young children has replaced the situations under the full planing and supervision of adults (Brooks, 2004) (Miller, 2005; Soga \& Gaston, 2016). As a result, the opportunity to interact directly with nature is an experience gradually being removed from childhood (Kahn, \& Kellert, 2002) (Hart \& Raver, 1999). Due to the reduction of this link, they spend much of their time indoors, and usually gain experience through the media, written language, and images. The virtual world has replaced the real world. Therefore, the aim of this study is to investigate the opportunities for improving the environmental condition of the children's cultural centres in different areas of Tehran. Based on the literature, it was hypothesized that the effects of nature oriented architecture on children may not be due solely to the direct interactions with natural environment but rather may be the indirect feelings and expectations of the users in different working areas.

\section{Research Method}

\subsection{Design}

This research utilized a descriptive correlation analysis to provide an overview of the requirements in the children's cultural buildings in Tehran. A survey was applied to collect response from participants and achieve the research objectives. The participants were asked to express their work experiences about the issues of existing centres and their attitude toward children's perception of nature and natureoriented architecture. To measure the variables, 21 sets of questions in the form of a five-choice Likert spectrum were prepared, where five was the highest value and one was the lowest. SPSS 16 software was applied for data analysis, and the results were investigated in two levels of descriptive and inferential statistics through correlation tests, $\mathrm{F}$ and Univariate tests. 


\subsection{Sample}

The statistical population of this study was 140 instructors working in the intellectual development centres for children in the north, south, east, and west of Tehran. Including instructors between 19 to45 years old. 42 respondents (30\%) announced their ages between 18-22 years old, 50 percent between 22 and 32 years, approximately 15 percent between 32 to 42 years, and 7 percent more than 42 years. Also, the duration of working years with children was asked and 20 percent were children's instructors for two years, 35 percent were between 2 to 5 years, 35 percent 5 to 10 years, 5 percent between 10 to 15 years and 5 percent announced that their experience with children more than 15 years.

\subsection{Validity of the questionnaire}

Validity highlights the appropriation of the data collection instrument and the statistical tests used to assess the main outcomes of the research. It is vital in the research process since the insufficient and inappropriate instrument can make the research and its findings impracticable and invalid. Content validity in current research was enhanced, by referring to the consensus of the academic experts and professors on the indicators.

\subsection{Reliability of the questionnaire}

Reliability is concerned about the consistency across the parts of a measuring instrument (Huck, 2007). A scale would have high internal consistency reliability if its items are correspond and measure the same concept (Huck, 2007, Robinson, 2009). Current study utilised Cronbachs' Alpha Coefficient to examine the reliability of the questionnaire. Accordingly, 30 primary data from responded questionnaires have been entreated to the SPSS and then its coefficient was calculated. These findings have been indicated in table 2 .

\begin{tabular}{|c|l|c|}
\hline & variables & Cronbachs' Alpha Coefficient \\
\hline 1 & Interior design & 0.79 \\
\hline 2 & facilities & 0.83 \\
\hline 3 & Safety and amenity & 0.74 \\
\hline 4 & Natural materials and elements & 0.81 \\
\hline 5 & Natural environment & 0.85 \\
\hline total & \multicolumn{2}{|c|}{0.92} \\
\hline
\end{tabular}

Table 2. Cronbachs' Alpha Coefficient of the questions

\subsection{Studied centres}

The investigated centres in this study were "The child and adolescent intellectual development centres". The history of these centres date back to 1965 and they have branches in different cities in Iran. The main aim of their establishment was to develop culture, literature, education, and art for children.

Nineteen different centres studied in this research included:

- Centres No. 22, 28, 30, 32 and 44 in the east of Tehran

- Centres No. 8, 7, 17, 20, 24 and 35 in the south of Tehran

- Centres No. 16, 11, 24 and 43 in the north of Tehran

- Centres No. 38,37,39 and 40 in the west of Tehran 


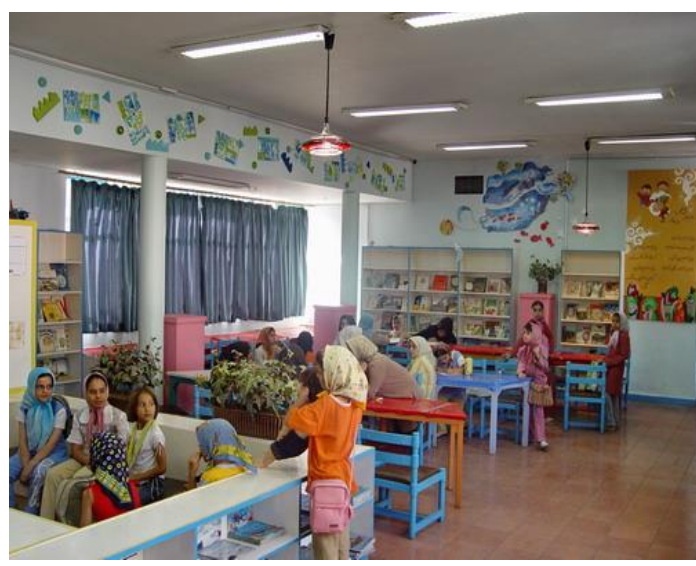

Figure 1. Children's cultural Centre No 28 (East of Tehran)

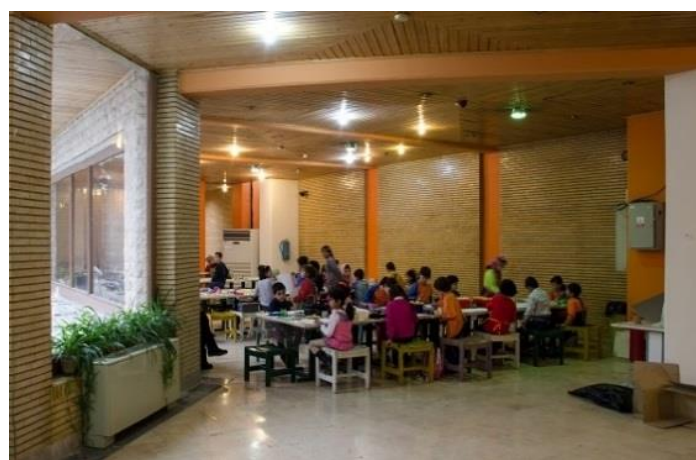

Figure 2. Children's cultural Centre No 37 (West of Tehran)

\section{Findings}

\subsection{Test results}

The questionnaire consisted of 21 main questions, in two parts; the issues in children's cultural centres and suggestions that can improve the quality of the studied environments according to the organic design criteria. Table 3 presents the results obtained from the analysis of variances.

\begin{tabular}{|l|l|c|c|}
\hline & Questions & Mean & Variance \\
\hline 1 & $\begin{array}{l}\text { The shape, size, and function of this place are suitable } \\
\text { for children }\end{array}$ & 2.7 & 1.55 \\
\hline 2 & $\begin{array}{l}\text { The design of this space is based on the physical } \\
\text { characteristics of children }\end{array}$ & 2.75 & 1.94 \\
\hline 3 & $\begin{array}{l}\text { The dimensions of the furniture and equipments are } \\
\text { suitable for children }\end{array}$ & 2.8 & 1.67 \\
\hline 4 & $\begin{array}{l}\text { Access and movements of children at this place is } \\
\text { happening easily }\end{array}$ & 2.83 & 1.49 \\
\hline 5 & The form of the spaces is flexible for various activities & 3.15 & 1.39 \\
\hline 6 & Painting in this place fits the spirit of children & 3 & 1.19 \\
\hline 7 & Lighting in this place is suitable for children's training & 2.85 & 0.75 \\
\hline 8 & The sound control in this place is well done & 2.87 & 1.29 \\
\hline
\end{tabular}




\begin{tabular}{|c|c|c|c|}
\hline 9 & $\begin{array}{l}\text { The comfort and safety of the children are well- } \\
\text { maintained in this place }\end{array}$ & 3.2 & 1.19 \\
\hline 10 & $\begin{array}{l}\text { the design of this place is based on special creativity } \\
\text { for children }\end{array}$ & 3 & 1.45 \\
\hline 11 & $\begin{array}{l}\text { The composition of warm colors in the walls is } \\
\text { effective in the formation of creativity and learning of } \\
\text { the children }\end{array}$ & 3.58 & 1.94 \\
\hline 12 & $\begin{array}{l}\text { This educational environment can provide the child } \\
\text { with mental and emotional intelligence if combined } \\
\text { with nature }\end{array}$ & 3.4 & 1.7 \\
\hline 13 & $\begin{array}{l}\text { Activities such as social participation, intuitive and } \\
\text { verbal skills for children occur in more } \\
\text { environmentally-related spaces }\end{array}$ & 3.75 & 2 \\
\hline 14 & $\begin{array}{l}\text { In open and natural environments, interaction } \\
\text { between the child and the instructor is greater and } \\
\text { training is more effective }\end{array}$ & 3.2 & 1.25 \\
\hline 15 & $\begin{array}{l}\text { Increasing natural lighting improve the children's } \\
\text { creativity, behavior and learning }\end{array}$ & 3.05 & 1.45 \\
\hline 16 & $\begin{array}{l}\text { The presence of colors close to natural elements has } \\
\text { positive effects on the intelligence and creativity of the } \\
\text { children }\end{array}$ & 3 & 1.51 \\
\hline 17 & $\begin{array}{l}\text { Outdoor education improves children's learning, } \\
\text { creativity and behavior }\end{array}$ & 3.1 & 1.45 \\
\hline 18 & $\begin{array}{l}\text { Designing the play areas in combination with nature } \\
\text { improve spiritual, social, and moral growth }\end{array}$ & 3.3 & 2.12 \\
\hline 19 & $\begin{array}{l}\text { Being able to paint on the walls in educational } \\
\text { environments will increase a child's interaction with } \\
\text { the environment and the level of learning and } \\
\text { creativity. }\end{array}$ & 3.2 & 1.77 \\
\hline 20 & $\begin{array}{l}\text { The use of natural elements during training process, } \\
\text { promotes children's learning and morals. }\end{array}$ & 3.1 & 2.6 \\
\hline 21 & $\begin{array}{l}\text { The use of natural materials (wood, stone, flowers, ...) } \\
\text { for building the spaces has a beneficial effect on the } \\
\text { efficiency of the children's sensitivity and creativity }\end{array}$ & 3.15 & 1.74 \\
\hline
\end{tabular}

Table 3. Indicators of central tendency and dispersion of the responds to the questionnaire

The results from the first part of the questionnaire indicate that the mean score for most of the items on important issues (questions 1 to 10) is lower than the average of 3. In general, in the studied samples, the most essential problems, according to the instructor's opinion are the shape, size, and function of the spaces. Besides, the physical characteristics of children have not been considered entirely in these areas. Among the problems, the comfort and safety of children are considered the least critical issues.

The second part of the questionnaire aimed to investigate the use of organic architecture principles for improving the conditions of cultural centres. Table 4 displays the central dispersion statistics of the research variables. It indicates that all variables are reported over the average of the population, and they have higher scores than the average community.

The respondents agreed that employing the principles of organic architecture could have a favourable impact on environmental improvement in cultural centres. In this regard, the effect of activities such as social participation, intuitive and verbal skills in the environments linked to nature has been more highlighted and compared to other items, have assigned more scores. On the other hand, the 
composition of warm natural colours in the walls and furniture, as well as the integration of open and closed spaces were less importance.

\begin{tabular}{|l|l|l|}
\hline Variable & Mean & Standard deviation \\
\hline $\begin{array}{l}\text { The most important problems for respondents are the } \\
\text { suitability of space design and the dimensions of the } \\
\text { furniture and equipment according to the physical } \\
\text { characteristics of the children. }\end{array}$ & 2.98 & 0.88 \\
\hline $\begin{array}{l}\text { Applying the principles of organic architecture can have a } \\
\text { beneficial effect in improving social participation, intuitive } \\
\text { and verbal skills for children in the cultural complex. }\end{array}$ & 3.22 & 1.178 \\
\hline
\end{tabular}

Table 4. Central scattering statistics of research variables

Table 5 and Figure 3 represents the responses of the studied people in a partial manner. According to the results, the centres in east and south of Tehran the most critical issues are related to the appropriateness of the space design and the dimensions of furniture and equipment based on the physical characteristics of the children. While in the north and west centres, these issues have an average score of less than 3 , and they are less problematic in this regard.

\begin{tabular}{|c|c|c|c|c|c|c|c|c|}
\hline $\begin{array}{l}\text { Independent } \\
\text { Variable }\end{array}$ & $\begin{array}{l}\text { Dependen } \\
\text { t Variable }\end{array}$ & $\begin{array}{l}\text { Groups' } \\
\text { Mean }\end{array}$ & uired & $\mathrm{F}$ & $\begin{array}{l}\text { The } \\
\text { Significance } \\
\text { Level }\end{array}$ & $\begin{array}{l}\text { Eta } \\
\text { Coeffici } \\
\text { ent }\end{array}$ & $\begin{array}{l}\text { Eta } \\
\text { Squared }\end{array}$ & $\begin{array}{l}\text { Confirming } \\
\text { or Rejecting } \\
\text { the } \\
\text { Hypothesis }\end{array}$ \\
\hline \multirow[t]{4}{*}{$\begin{array}{l}\text { Different parts } \\
\text { of Tehran }\end{array}$} & \multirow{4}{*}{$\begin{array}{l}\text { Main } \\
\text { issues in } \\
\text { cultural } \\
\text { centers }\end{array}$} & $\begin{array}{l}\text { North } \\
\text { centers }\end{array}$ & 2.4 & \multirow[t]{4}{*}{$\begin{array}{l}14.3 \\
7\end{array}$} & \multirow[t]{4}{*}{0.0001} & \multirow[t]{4}{*}{0.35} & \multirow[t]{4}{*}{0.13} & \multirow{4}{*}{$\begin{array}{l}\text { Rejecting H1 } \\
\text { Hypothesis } \\
\text { and } \\
\text { H0 } \\
\text { Hypothesis }\end{array}$} \\
\hline & & $\begin{array}{l}\text { East } \\
\text { centers }\end{array}$ & 4.46 & & & & & \\
\hline & & $\begin{array}{l}\text { South } \\
\text { centers }\end{array}$ & 3.92 & & & & & \\
\hline & & $\begin{array}{l}\text { West } \\
\text { centers }\end{array}$ & 2.84 & & & & & \\
\hline
\end{tabular}

Table 5. Descriptive Statistics: F ANOVA

According to the above tests, since the sig amounts (significance level) in the ANOVA table is less than 0.05 (i.e., 0.0001), the hypothesis is confirmed. There is a significant difference between the instructor's opinions in studied centres. The cultural centres in the east of Tehran, with an average score of 4.46 has the highest rate. South, west, and north centres have the scores of 3.92, 2.84, and 2.40, respectively. Moreover, the Eta coefficient in the Eta table is 0.35 that reports a moderate intensity of the relationship between the two variables. The Eta squared also indicates that 0.13 percent of the dependent variable (organic architecture) could be explained with the variance of the independent variable (cultural environments for children). It means that in the studied cultural centres, there is a moderate level of relationship between organic architecture and the designed spaces for children. 


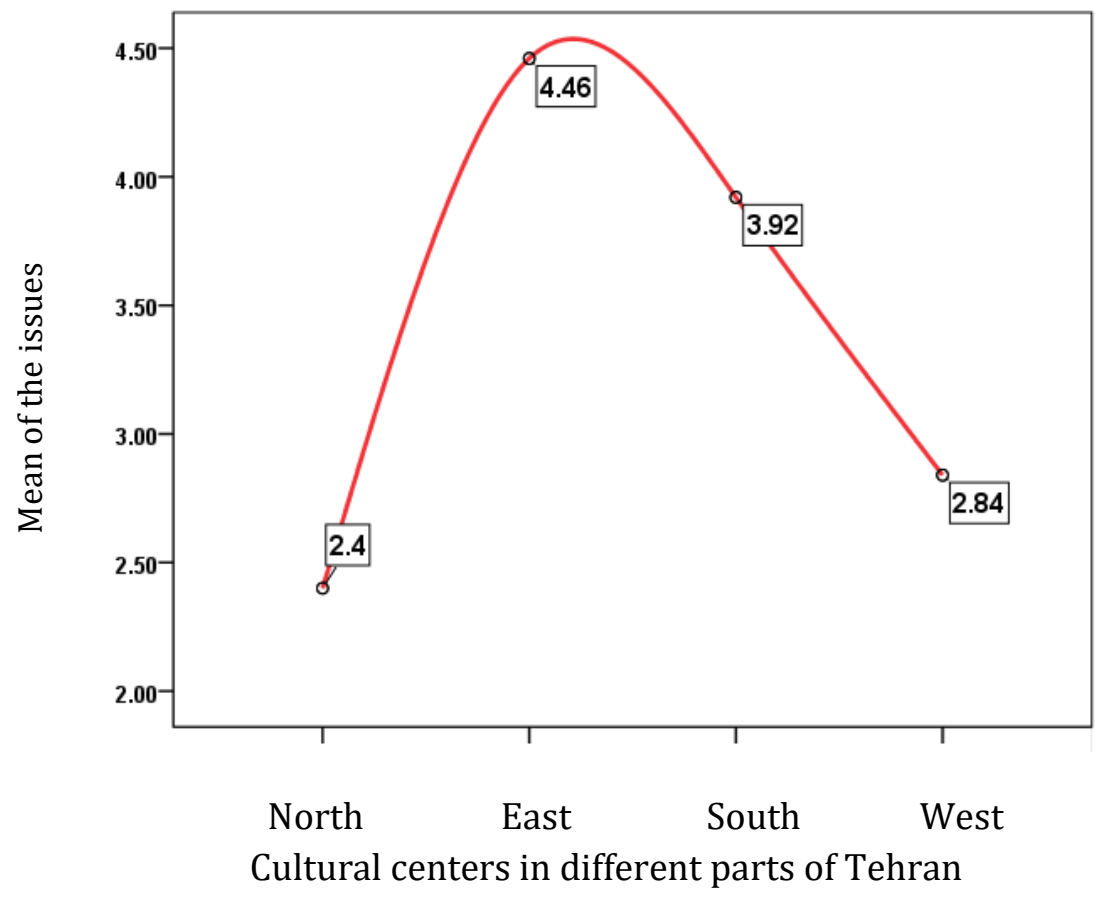

Figure 3. Acquired Average relationship of the responds in the case studies

Table 6 and Fig 4 indicates the instructor's point of view about the proposed suggestions. According to the results, centres in north and west of Tehran, the principles of organic architecture have scored a higher mean (above average 3) and the respondents agreed more with the effects of the suggested criteria for improvement of the conditions. While, in the east and south centres, the results have not been able to allocate the average score of 3 , and the impact of the principles of organic architecture has been less noted.

\begin{tabular}{|c|c|c|c|c|c|c|c|c|}
\hline $\begin{array}{l}\text { Independent } \\
\text { Variable }\end{array}$ & $\begin{array}{l}\text { Dependent } \\
\text { Variable }\end{array}$ & $\begin{array}{l}\text { Groups' } \\
\text { Mean }\end{array}$ & uired & $\mathrm{F}$ & $\begin{array}{l}\text { The } \\
\text { Significance } \\
\text { Level }\end{array}$ & $\begin{array}{l}\text { Eta } \\
\text { Coeffici } \\
\text { ent }\end{array}$ & $\begin{array}{l}\text { Eta } \\
\text { Squared }\end{array}$ & $\begin{array}{l}\text { Confirming } \\
\text { or Rejecting } \\
\text { the } \\
\text { Hypothesis }\end{array}$ \\
\hline \multirow{4}{*}{$\begin{array}{l}\text { Different } \\
\text { parts } \\
\text { Tehran }\end{array}$} & \multirow{4}{*}{$\begin{array}{l}\text { Main } \\
\text { issues in } \\
\text { cultural } \\
\text { centers }\end{array}$} & $\begin{array}{l}\text { North } \\
\text { centers }\end{array}$ & 4.53 & \multirow[t]{4}{*}{$\begin{array}{l}18.4 \\
8\end{array}$} & \multirow[t]{4}{*}{0.0001} & \multirow[t]{4}{*}{0.48} & \multirow[t]{4}{*}{0.21} & \multirow{4}{*}{$\begin{array}{l}\text { Confirming } \\
\text { H1 } \\
\text { Hypothesis } \\
\text { and } \\
\text { Rejecting } \\
\text { H0 } \\
\text { Hypothesis }\end{array}$} \\
\hline & & $\begin{array}{l}\text { East } \\
\text { centers }\end{array}$ & 2.5 & & & & & \\
\hline & & $\begin{array}{l}\text { South } \\
\text { centers }\end{array}$ & 1.49 & & & & & \\
\hline & & $\begin{array}{l}\text { West } \\
\text { centers }\end{array}$ & 3.75 & & & & & \\
\hline
\end{tabular}

Table 6. Descriptive Statistics: F ANOVA

According to the results, because the sig amounts in the ANOVA table, is equal to 0.0001 , and this value is less than 0.05 , so the second hypothesis is confirmed, and it can be concluded that there is a significant relationship between the centre's location and employing the principles of organic architecture. In the north and west centres, due to the better economic conditions of the people and fewer issues in the cultural centres, the instructors have been more concerned about the use of organic architecture principles. While, the importance of these principles in east and south centres have received less attention due to the existence of other important issues like size, and function of the areas as well as the lighting and sound control. 


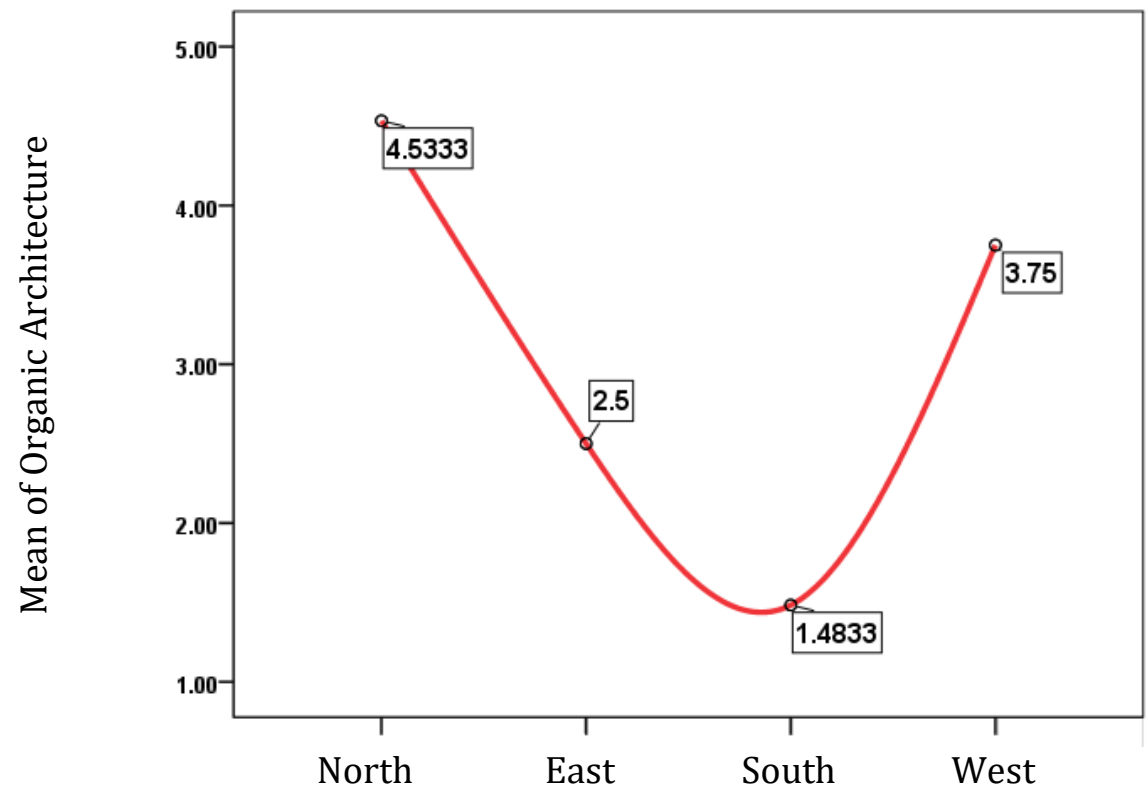

Cultural centers in different parts of Tehran

Fig. 4. Acquired Averages from respondents in different centers

\section{Conclusion}

Present study has indicated the issues in children's cultural centres in Tehran and the importance of designing and planning these places, according to the requirements of the children as users. These places are often designed similar to other public areas and are solely to abide by standards such as opening dimensions, and height of the stairs and fences. Besides, our study makes an important effort towards an understanding of the influence of nature on children and their environmental interactions.

The results from the responded questionnaire showed the considerable impact of the proposed indicators on children's relationship with nature. Also, considering the visual factors, the colours and appropriate natural lighting, as well as providing thermal comfort and noise control, can create a significant impact on the efficiency of children's learning and creativity. The studied places should have the same flexibility as nature so that they can be re-arrange if needed. Besides, new experiences would increase the curiosity of children and their mental growth. Therefore, it is important to educate young children so that their natural sense of relatedness to nature is developed, and so that they obtain information that helps them understand this natural relationship with nature. The quality of environmental education for young children determines their understanding of self and a foundational orientation toward respecting and caring for the natural environment.

The data used in this paper are cross-sectional and only 19 centres were utilised, therefore limiting the generalization to other such centres. Also, results are based on self-report survey data and subject to common method bias. As such, longitudinal studies are recommended for future research, to help the instructors improve the way they percept about nature. Future avenues of research are required to allow for a better understanding of the ways that children construct and allocate meanings to nature in differing circumstances, and what are the main meanings responsible for. 


\section{References}

[1] Beery, T. H., \& Lekies, K. S. (2018). Childhood collecting in nature: Quality experience in important places. Children's Geographies, Online at: https://doi.org/10.1080/14733285.2018.1463431.

[2] Balling, J.D. ,Falk, J.H., (1982), Development of Visual Preferences for Natural Environment, Journal of Environmental Behavior, Vol.4 No. 1, pp. 5-28.

[3] Brooks D., (2004), On Paeadie Deive: How We Live New (and Always Have) in the Future Tenes, New York, Simon Schuster, pp.142-143.

[4] Browning, W.D., Ryan, C.O., Clancy, J.O., (2014), 14 Patterns of Biophilic Design. New York: Terrapin Bright Green, pp.91-97.

[5] Dehkhoda, A.A., (1998), Dehkhoda Dictionary, Tehran, University of Tehran, 18-21.

[6] Fjørtoft, I., (2004), Landscape as Playscape: The Effects of Natural Environments on Children's Play and Motor Development,Children, Youth and Environments, Collected Papers, Vol.14 No.2, pp. 21-44.

[7] Frumkin H ,Fox, J., (2011), Contact with nature. In A.L. Dannenberg, H., Frunmkin, R. J. Jackson, Making Healthy Places: Designing and Building for Health, Well-being and Sustainability, Washington: Island press, pp.106-102.

[8] Gharebigloo, M., (2010), City Responsibilities toward Children's Playground, Pershar Monthly, Sep., No. 10, pp.21-22.

[9] Hagan, S., (2012), Taking Shape: A New Contract between Architecture and Nature, New York: Routledge Press, pp.79-80.

[10] Hart R., Raver A., (1999), Tutored By the Great Outdoors at a Southern Pines Playground, New York Times.

[11] Hosseini, A.S, (1997), Analysis of the nature of creativity and its methods of cultivation, Ph.D. Thesis, Tarbiat Modares University, Tehran, Iran.

[12] Huck, S. W. (2007), Reading Statistics and Research, United States of America, Allyn \& Bacon.

[13] Joy, Y., (2007), Architectural Lessons from Environmental Psychology: The Case of Biophilic Architecture, Journal of Review of General Psychology, Vol.11 No.4, pp.305-328.

[14] Kahn, P. H. \& Kellert S. R. (Eds.), (2002), Children and Nature: Psychological, Sociocultural, and Evolutionary Investigations. Cambridge, MA: The MIT Press,pp. 99-100.

[15] Miller, J. R. (2005). Biodiversity conservation and the extinction of experience, Trends in Ecology \& Evolution, Vol.20 No.8, pp. 430-434.

[16] Mortazavi, Sh., (1997), Educational spaces from the environmental psychology point of view, Organization of modernization, development and equipping of schools, Volume I, pp.67-69. 
[17] Muscovitch, A., (1980), Study if children's perception of the neighborhood, Canada Mortgage and Housing Corporation, Ottava.

[18] McAndrew, F.T., (2008), Environmental Psychology, United States: Brooks/Cole Press, pp.110-112.

[19] Mygind L., Kjeldsted, E., Hartmeyer, R., Mygind, E., Bølling, M., Bentsen, P., (2019), Mental, physical and social health benefits of immersive nature-experience for children and adolescents: A systematic review and quality assessment of the evidence, Health \& Place, Vol.58 No.1, pp.102136.

[20] Nasr, S.H., (1998), The Viewpoints of Islamic thinkers about nature, Kharazmi publications, 34 .

[21] Pyle, R. M., (2002), Eden in a vacant lot: special places, species and kids in the neighborhood of life. In P. H. Kahn \& S. R. Kellert (Eds.), Children and nature: Psychological, sociological, and evolutionary investigations, Cambridge, MA: Massachusetts Institute of Technology Press, pp.305-327.

[22] ProficeC (2018)Natureas a livingpresence:Drawingsby Tupinamba'and New YorkChildren.PLoSONE 13(10):e0203870.

[23] Robinson, J. (2009), Triandis theory of interpersonal behaviour in understanding software privace behaviour in the South African context, Masters degree, University of the Witwater srand.

[24] Seyf, A.A., (2004), Psychology of Breeding, Knowledge Publishing, Tehran, pp.35-36.

[25] Shafaee, M. ,Madani, R., (2010), Design Principles of Educational Facilities for Children Based on the Child's Creativity, Journal of Technology of Education, Vol.4 No 3, pp.215-222.

[26] Shamsuddin, M. S., \& Said, I., (2008), "Middle childhood children interaction with home and neighborhood gardens in urban and rural setting, In: ICBEDC 2008 -2ND International Conference on Built Environment in Developing Countries.

[27] Tavakoli, M., Saeedi Rezvani, N., (1997), Creating Better Cities With Children and Adolescents, Drischel, David, Publishing Dibayeh, Tehran, pp.48-51.

[28] Tabatabaiyan, M., Abbasalizadeh Rezakalei, S., Fayyaz, R., (2014), The Effect of Nature on Children's Creativity, Urman Architecture and Urban Development, Vol.17 No.1, pp.91- 102.

[29] Tetsuro Hosaka, T., Numata, Sh., Sugimoto, K., (2018), Research Note: Relationship between childhood nature play and adulthood participation in nature-based recreation among urban residents in Tokyo area, Landscape and Urban Planning, Vol.180 No. 1, pp.1-4.

[30] Taylor A., Kuo F., Sullivan W., (2001), The surprising connection to green play settings, Environment and Behavior, Vol.33 No1, pp.54-77.

[31] Zamani, Z., (2009), Child, Nature, City, the Necessity of Restoring Natural Landscapes to the Children's Living Environment, Parast Journal, Vol.4 No.1, pp.61 -58. 
International Journal of Engineering and Management Sciences (IJEMS) Vol. 5. (2020). No. 1

DOI: 10.21791/IJEMS.2020.1.21

[32] Zamani, P., (1999), An Introduction to the Presence of Nature in Architecture, 2nd Iranian Architecture and Urbanism Congress, Nature Proceedings in the Art of the East, Art Academy, Tehran, Iran. 